\title{
Corrigendum: Die wisselende rol van kontinuïteit en diskontinuïteit in die geskiedenis van die filosofie en die wiskunde
}

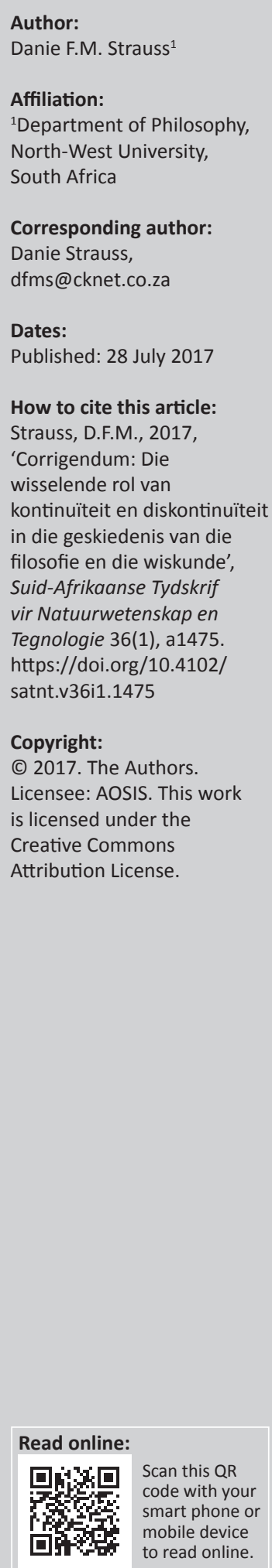

In die aanvanklike gepubliseerde weergawe van hierdie artikel, is Danie F.M. Strauss se verwantskap verkeerdelik gelys as: 'Department of Philosophy, University of the Free State, South Africa'. Sy korrekte verwantskap moet wees: 'Department of Philosophy, North-West University, South Africa'. Hierdie fout is reggestel in die PDF-weergawe van die artikel. Die outeur vra om verskoning vir enige ongerief wat dit mag veroorsaak het. 


\section{Die wisselende rol van kontinuïteit en diskontinuïteit in die geskiedenis van die filosofie en die wiskunde}

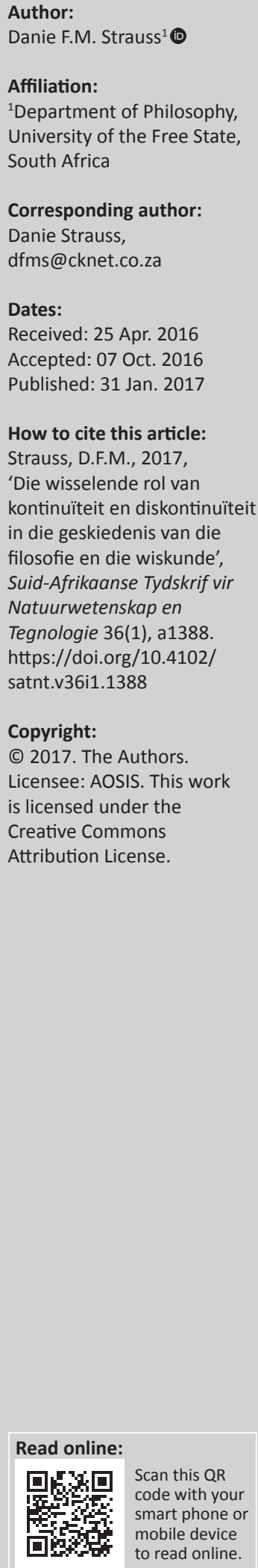

Hierdie artikel wil lig werp op die onvermydelikheid van diskreetheid en kontinuïteit as primitiewe (ondefinieerbare) verklaringswyses in die geskiedenis van die filosofie en die wiskunde. Dit beliggaam die algemene uitdaging om rekenskap van die samehang van iets wat uniek is te gee. Gödel beklemtoon die samehang van 'primitiewe begrippe'. Die Griekse filosofie het reeds die ruimtelike geheel-dele-relasie - en die oneindige verdeelbaarheid daarvan - ontdek. Gedurende en na die Middeleeue het filosowe wipplank gery tussen ' $n$ atomistiese waardering van die kontinuum en die teenoorgestelde daarvan, wat byvoorbeeld in die denke van Leibniz aangetref word as die gepostuleerde wet van kontinuïteit (lex continui). Die ontdekking van 'inkommensurabiliteit' (irrasionale getalle) deur die Grieke het aanleiding gegee tot die eerste grondslagkrisis van die wiskunde en die geometrisering daarvan. Leibniz en Newton kon die probleme rondom die limietbegrip nie besleg nie en spoedig sou dit tot die derde grondslagkrisis van die wiskunde aanleiding gee. Dit het Frege en die 'kontinuum-teoretici' daartoe gebring om prioriteit aan die kontinuum te gee - diskreetheid is 'n katastrofe. Onlangs waardeer Smooth Infinitesimal Analysis kontinuïteit as iets wat 'n 'ongebroke en ononderbroke geheel' daarstel. Die intuïsionistiese wiskunde het opnuut aangesluit by die klem op die ruimtelike geheel-delerelasie. Ondanks pogings om kontinuitteit eksklusief aritmeties en ruimtelik te verstaan bevestig die geskiedenis van die filosofie en die wiskunde onmiskenbaar dat die medekondisionerende rol van hierdie twee wyses van verklaring 'n konstante metgesel in die nadenke oor kontinuïteit en diskontinuïteit sou bly. (Die rol van kontinuïteit en diskontinuïteit in die fisika en biologie sal in 'n aparte artikel ondersoek word.)

The changing role of continuity and discontinuity in the history of philosophy and mathematics. The aim of this article is to highlight the inevitability of employing discreteness and continuity as primitive (indefinable) modes of explanation in the history of philosophy and mathematics. It embodies the general challenge to account for the coherence of what is unique. Gödel emphasises the coherence of 'primitive concepts'. Greek philosophy already discovered the spatial whole and/or parts relation with its infinite divisibility. During and after the medieval era philosophers toggled between an atomistic appreciation of the continuum and its opposite, for example found in the thought of Leibniz who postulated his law of continuity (lex continui). The discovery of incommensurability (irrational numbers) by the Greeks caused the first foundational crisis of mathematics, as well as its geometrisation. Leibniz and Newton did not resolve the problems surrounding the limit concept and soon it induced the third foundational crisis of mathematics. It caused Frege and the 'continuum theoreticians' to assign priority to the continuum - discreteness is a catastrophe. Recently Smooth Infinitesimal Analysis appreciated what is 'continuous' as constituting 'an unbroken or uninterrupted whole'. Intuitionistic mathematics once more proceeded from an emphasis on the whole and/or parts relation. In spite of alternating attempts to understand continuity exclusively, either in arithmetical or in spatial terms, the history of philosophy and mathematics undeniably confirms that the co-conditioning role of these two modes of explanation remains a constant element in reflections on continuity and discontinuity. (The role of continuity and discontinuity within the disciplines of physics and biology will be discussed in a separate article.)

\section{Inleiding}

Hierdie artikel beoog om die onvermydelike gebruik van die terme 'kontinuïteit' en 'diskontinuïteit' (diskreetheid) te belig - terme wat ten nouste aan die aard van getal en ruimte verbonde is. Dit sal blyk dat diskreetheid en kontinuïteit as unieke, maar wederkerig samehangende verklaringswyses die geskiedenis van die filosofie en die wiskunde in belangrike opsigte bepaal het. ${ }^{1}$ 
Hierdie taakstelling sluit aan by Gödel se oortuiging dat kennis van primitiewe begrippe vereis dat hulle intuïtief in hul uniekheid en samehang verstaan moet word. ${ }^{2}$ Ons wil aantoon hoedanig die verhouding tussen kontinuïteit en diskontinuïteit histories betekenisvolle kontoere bied waarbinne die ontwikkeling van die filosofie en die natuurwetenskappe (in hierdie artikel toegespits op die wiskunde) verstaan kan word.

Die verhouding tussen kontinuïteit en diskontinuïteit verteenwoordig sekerlik een van die klassieke grondprobleme wat dwarsdeur die geskiedenis van die filosofie en die vakwetenskappe 'n besondere rol sou speel. Besinning oor die verhouding tussen (dis-)kontinuïteit (en diskreetheid) sal bykomend aan die lig bring dat dit ook ten nouste met hierdie ander klassieke probleme verweef is. Voorts sal dit blyk dat nadenke oor die aard van kontinuïteit ook verband hou met '-ismes' soos die atomisme, holisme, intuïsionisme, realisme en nominalisme. Die belangrike onderliggende perspektief sluit egter aan by die bovermelde insig van Gödel, naamlik dat beide diskreetheid en kontinuiteit uiteindelik nie nader gedefinieer kan word nie, hoeseer die sin daarvan slegs tot openbaring kom in samehang met ander ongedefinieerde terme (primitives).

Ons let egter allereers op enkele historiese aanknopingspunte alvorens ons aandag skenk aan die wyse waarop hierdie grondprobleem in die wiskunde na vore getree het.

\section{Historiese agtergrond}

Die vroegste Griekse filosowe was op soek na die 'oorsprong' (archē) van alles. Water (Thales: 600 v.C.), vuur (Herakleitos: 500 v.C.) en lug (Anaksimines: 550 v.C.) was vroeë keuses. 'n Uitsonderlike posisie is deur Anaksimandros (575 v.C.) ingeneem met sy keuse vir die apeiron, die oneindig onbegrensde (Diels \& Kranz 1959-1960; Thales, B Fragment [vervolgens verkort tot: Fr] 3; Anaksimines, Diels \& Kranz, B Fr. 3; Pythagoras (570-504), Diels \& Kranz, B Fr. 3; en Anaksimandros, Diels \& Kranz, B Fr. 1).

Dit is opvallend dat Anaksagoras (500-428) stel dat die apeiron bo dood en verganklikheid verhewe is (Diels \& Kranz, B Fr. 2) en dat dit bo dood en verganklikheid verhewe is (Diels \& Kranz B Fr. 3). Hierdie eienskappe vind ons ook in Parmenides (500 v.C.) se didaktiese gedig waar hy die (statiese) syn tipeer as ongebore en onverganklik, dat dit nie was nie en nie sal wees nie, want dit is in die hede tesame voorhande as 'n geheel, een, samehangend (kontinu) (Diels \& Kranz, B Fr. 8:3-6). Tog beklemtoon Parmenides dat die syn nie deelbaar is nie omdat dit volkome gelykgeaard is (B Fr. 8:22). ${ }^{3}$

Empedokles het die een ondeelbare synsgeheel van Parmenides verdeel in 'vier wortelvorme' wat onverwoesbaar

2. Godel "insisted that to know the primitive concepts, one must not only understand
their relationships to the other primitives but must grasp them on their own, by a their relationships to the other primitives but must grasp
kind of "intuition"' (aangehaal deur Yourgrau 2005:169).

3.'n Vitalistiese bioloog uit die 20ste eeu E.W. Sinnott sou hierby aansluit wanneer hy verklaar dat 'vorm' 'n kategorie is wat totaal van materie verskil - ' $[$ it] is a continuous entity and cannot be divided into pieces' (Sinnott 1963:199). en onverganklik is: water, aarde, vuur en lig. Na sy mening is die wisselgang van twee sielekragte (liefde en haat) vir die dinamiek van die wêreldgebeure verantwoordelik (Diels \& Kranz B Fr. 6 e.v.). Die beperking wat in die ondeelbare aard van die syn (Parmenides) of in die vier synsvorme (Empedokles) opgesluit lê, word weliswaar in die denke van Zeno en Anaksagoras te bowe gekom.

\section{Van eindeloosheid na oneindige verdeelbaarheid}

In sy bekende B Fr. 3 betrag Zeno die probleem van die begrensdheid en die onbegrensdheid van identiese dinge. In die uiteensetting van hierdie derde Fragment begin Zeno in beide gevalle met veelheid as 'n gegewe. Indien veelheid bestaan, só formuleer Zeno sy eerste argument, dan moet daar noodwendig presies soveel dinge bestaan as wat daar werklik bestaan, niks meer en niks minder nie. Wanneer daar egter soveel dinge bestaan as wat daar bestaan, is die getal daarvan begrens. Die keersy van die argument begin eweseer met die bestaan van veelheid. Maar omdat daar steeds tussen twee bestaande dinge ook ander bestaande dinge is, is die bestaande dinge ooreenkomstig hul getal onbegrens.

Die eerste argumentasielyn redeneer vanaf die dele na die geheel (dan bly die hoeveelheid daarvan dieselfde, d.i. begrens), terwyl die tweede argument by die geheel begin en dan voortbeweeg na die eindelose verdeelbaarheid daarvan, wat vanself tot die konklusie van 'n onbegrensde aantal lei. Herman Fränkel gebruik die geheel-dele-relasie om Fragment 3 van Zeno verstaanbaar te maak (sien Fränkel 1968:425ff. en ook bl. 430).

Anaksagoras kontinueer elemente uit die denke van Anaksimandros en Parmenides wanneer hy beweer dat aangesien daar glad nie 'n kleinste kan wees nie, niks sig kan afsonder of op sigself kan bestaan nie, want soos in die begin moet alles nou ook tesame wees (Diels \& Kranz B Fr. 6). In hierdie één wêreldordening is niks afgesonder van iets anders, asof dit met' $n$ byl afgekap is nie (Diels \& Kranz B Fr. 8). Slegs die rede (nous) is nie met enigiets vermeng nie, want dit is outonoom en bestaan alleen, selfstandig, vir sigself (Diels \& Kranz B Fr. 12). Die klem verskuif by Anaksagoras na die nous, want hy tipeer dit as immer durend en nou ook ewig (Diels \& Kranz B Fr. 14). ${ }^{4}$

Hierdie sienings het die weg geopen vir die erkenning dat iets wat kontinu is, nie alleen verdeelbaar is nie, maar ook toelaat dat sulke verdelings eindeloos voortgesit kan word dit wil sê dat dit oneindig verdeelbaar is. Aristoteles (384-322) het hierdie insig nog ' $n$ tree verder gevoer, want een van sy bekende stellings is dat iets wat kontinu is uit dele bestaan wat elk ook oneindig verdeelbaar is. Tegelyk tref hy 'n duidelike onderskeid tussen oneindigheid in die sin van 'n eindelose suksessie en oneindigheid in die rigting van verdeling (Aristoteles 2001:267; Phys. 206a32-35). In Boek VI 4.Anaksagoras gebruik die woorde 'altyd wees' (á $\dot{\varepsilon} \sigma \tau)$ wat aan die Griekse aanduiding van ewigheid ( $\alpha i \dot{\omega} v)$ verwant is. 
van sy werk 'Physica' het hy begryp dat die geheel/delerelasie die suksessief oneindige 'na binne keer' (Aristotle 2001:327; Phys. 231b15-18).

Thomas Aquinas gebruik 'n afdalende reeks abstraksies om by ' $n$ eendimensionele lyn uit te kom. Wiskundige figure onderskei hulself van natuurlike liggame deurdat hulle oneindig verdeelbaar is. Aansluitend by die erfenis van Aristoteles word 'n punt as die beginsel van 'n lyn gesien (Aquinas: 1945), wat daarop dui dat 'n bepaalde lynstuk twee eindpunte besit ('cuius extremitates sunt duo puncta' - Thomas Aquinas, S. Th. I,85,8). Dit blyk ook uit sy siening dat daar nie opeenvolgende punte kan wees nie, want tussen twee willekeurige punte is daar altyd 'n oneindige aantal tussenliggende punte (Inter quaelibet duo puncta sunt infinita puncta media, cum nulla duo puncta consequantur se invicem sine medio - S.Th, I,53,2). Met ' $n$ beroep op Aristoteles se Phsyica (III), stel Thomas Aquinas dat 'n grootte oneindig verdeelbaar is, aangesien kontinuïteit gedefinieer word as dit wat oneindig verdeelbaar is (magnitude is infinitely divisible, for the continuous is defined [as] that which is infinitely divisible, as is clear from Phys. iii) (S.Th. I,7.3). ${ }^{5}$

\section{Atomisme in die geding}

Gedurende die veertiende eeu is veel aandag aan die probleem insake die samestelling (komposisie) van 'n kontinuum gegee. In hierdie tyd was die atomistiese reaksie op Aristoteles se siening tweevoudig:

- Die eerste groep was oortuig dat enige kontinuum saamgestel is uit 'n eindige getal 'ondeelbares' (punte wat nie verdeel kan word nie) wat onmiddellik aan mekaar gegrens het (Walter Chatton, Gerard van Odo \& Nicolas Bonetus).

- Die tweede siening aanvaar 'n oneindige aantal 'ondeelbares' (Henry van Harclay).

Murdoch wys daarop dat bykans alle veertiende-eeuse kritici van indivisibilism die bedoeling gehad het om die kontradiksies bloot te lê wat voortspruit uit die kombinasie van atomisme en die meetkunde. Hy beskou die werk van Thomas Bradwardine (in sy Tractatus de continuo) as een van die mees diepgaande weerleggings van die veertiende-eeuse atomisme waaroor ons beskik (Murdoch 1969:238 ff.).

Heytesbury behandel ook nog die kontinuum in terme van Aristoteles se siening van die oneindige verdeelbaarheid daarvan. Henry Harclay en Walter Chatton het aan die begin van die veertiende eeu egter die oneindige verdeelbaarheid ontken (Murdoch: 1982). Die term latitude (oorspronklik deur Hendrik van Ghent ingevoer), is aan die aard van 'n graad (degree) verbind in die sin van 'n domein waarin 'n gegewe vorm, complexion, kwaliteit of kwantiteit kan varieer. Die standaardkontras is tussen

5. Grootte bekyk kontinue uitgebreidheid vanuit ' $n$ geta............................. betref dit een, twe of meer dimensies en andersyds figureer grootte as ' betref dit een, twee of meer 'n lenensies en and getalsmaat van uitgebreidheid-'nlengtemat in an twee, en so meer. 'n Reguit lyn kan daarom nie as die kortste afstand tussen twee punte gesien word nie - die kontinue uitgebreidheid van 'n lyn val nie met die lengtemaat daarvan saam nie. ondeelbare vorme en dié wat 'n 'latitude' of domein van variasie besit (Sylla 1973:228-229).

Met betrekking tot die oneindige verdeelbaarheid van iets wat uitgebreid is, handhaaf Descartes ook nog die AristoteliesThomistiese siening wanneer hy stel dat geen atoom of 'n gedeelte van materie ondeelbaar is nie. Aangesien hierdie dele noodwendig uitgebreid is ${ }^{6}$, sal dit altyd moontlik wees om hulle in twee of meer kleiner dele te verdeel. Selfs wanneer God enige materiedeeltjie so klein mak dat geen skepsel by magte sal wees om dit verder te verdeel nie, sal dit nog steeds, kragtens die almag van God, vir Hom deelbaar wees: 'Wherefore, absolutely speaking, the smallest extended particle is always divisible, since it is such of its very nature' (Descartes 1965b:209).

\section{Die natuur maak geen spronge nie (natura non facit saltum)}

Leibniz worstel met dieselfde probleem, want teenoor sy diskrete, vensterlose monade aanvaar hy die lex continui (kontinuïteitswet) wat in die Latynse formulering daarvan stel dat die natuur geen spronge maak nie (natura non facit saltum) (Leibniz 1976:397). Hy het hierdie wet vir die eerste keer in 1687 geformuleer in 'n brief waarin hy in gesprek tree met die aanhangers van Descartes (Breidert 1976:1043). In sy New essays on the human understanding, wat eers byna 50 jaar na sy dood gepubliseer is, waardeer Leibniz hierdie wet 'as one of my most important and best verified maxims', naamlik 'that nature makes no leaps. This I called the law of continuity' (Leibniz 1965:152, vgl. bl. 156; Leibniz 1976:397). Die kontinuïteitswet dui daarop dat alles vir Leibniz samehangend (kontinu) is.

Waar Immanuel Kant die kosmologiese idee van die totaliteit van 'n gegewe geheel in sy Kritiek van die suiwere rede (KSR) bespreek, kies hy 'n suksessief oneindige verdeelbaarheid wat nooit volledig [ganz] is nie (Kant 1787-B:552). ${ }^{7}$ 'n Intuitief gegewe verskyning laat as quantum continuum ' $n$ oneindige verdeelbaarheid toe, maar wanneer 'n quantum discretum aangegee word, betref dit 'n Prinzipium (beginsel) van die rede (Vernunft) insake die transendentale verdeling van 'n verskynsel wat nooit as absoluut voltooid gesien kan word nie (Kant 1787-B:555). Dit beteken dat 'n geheel nooit as geheel op sigself 'volledig verdeeld' kan wees nie. Die oneindige verdeelbaarheid van 'n geheel moet gesien word as ' $n$ oneindige ry wat nooit voltooid is nie [als eine niemals $z u$ vollendete Reihe (unendlich)] (Kant 1787 -B:554-555). Dit gaan vir Kant oor 'n universele eienskap van (intuïtief gegewe) ruimtelike uitgebreidheid, waar die begrip van verdeelbaarheid apriori deur die menslike verstand verskaf word. Na Kant sou die swaartepunt van die besinning oor die aard van kontinuïteit egter geleidelik verskuif na ontwikkelinge binne die wiskunde self.

6.Hou hierby in gedagte dat die wesensaard van ' $n$ liggaam volgens Descartes uitsluitlik in uitgebreidheid te vind is: '. the nature of [a] body consists not in weight, hardness, colour and the like, but in extension alone' (Descartes 1965b:200).

7.Die teksgedeelte in kursief is ' $n$ letterlike vertaling van Kant se Duitse uitspraak: 'welche sukzessivunendlich und niemals ganz ist'. 


\section{Die sirkelgang van diskreetheid en kontinuïteit}

Die erkenning van die oneindige verdeelbaarheid van ' $n$ kontinuum verteenwoordig ' $n$ gemeenskaplike insig wat in beide die filosofie en die wiskunde sedert die Griekse oudheid aanwesig is. Hoewel die idee van 'n kontinuum aan die aard van ruimte verbind word, was die Griekse wiskunde in die eerste plek aritmetika en nie meetkunde nie. Uiteraard hang dit daarmee saam dat die vroeë Griekse wiskunde beïnloed is deur die Pythagoriese opvatting van 'n 'arithmetica universalis', saamgevat in die welbekende spreuk: 'alles is getal' (Hasse \& Scholz 1928:5). Dit staan ook as die aritmetisering van die wiskunde bekend. Die krisis van die Griekse wiskunde het uit 'n meetkundige ontdekking voortgevloei - naamlik toe dit geblyk het dat die verhouding tussen die diagonaal en 'n sy van 'n reëlmatige vyfhoek (pentagram) 'inkommensurabel' is. Dit beteken dat dit nie uitgedruk kan word in terme van die relasie tussen twee heelgetalle nie. Histories gesien, dui dit op die ontdekking van die irrasionale getalle - hoeseer tegelyk besef moet word dat hierdie ontdekking nie tot 'n erkenning van die getalsaard van die reële getalle aanleiding gegee het nie.'n Intuïtionistiese wiskundige beskou nog steeds reële getalle as innerlik teenstrydige fiksies (Fischer 1933:82 e.v.).

Met hierdie ontdekking van irrasionale getalle is die relasie tussen kontinuïteit en diskontinuïteit (diskreetheid) in die sentrum van die (ontwikkeling van die) wiskunde geplaas.

In sy werk oor die Infinitesimalmathematik behandel Laugwitz juis die probleemverhouding tussen getalle en die kontinuum: Zahlen und Kontinuum. Hy verwys hierna as die polariteit tussen die geometriese kontinuum enersyds, en getalle $(1,2,3 \ldots)$ andersyds. Volgens hom word hierdie polariteit orals in die wiskunde en ook in die geskiedenis van die wiskunde aangetref. Die effek van die ontdekking van irrasionale getalle was, onder meer, dat elke getalsverhouding geometries voorgestel kan word, maar dat nie elke verhouding tussen lyne aritmeties voorgestel kan word nie (Laugwitz 1986:9). Lorenzen merk op dat aritmetika altyd na die teorie van die heelgetalle 1, 2, 3 ... verwys en beklemtoon dan Laugwitz se latere siening wanneer hy ook skryf: 'Elke getalsverhouding laat sig inderdaad geometries daarstel, maar nie elke lynverhouding laat 'n aritmetiese daarstelling toe nie' ${ }^{8}$

Fraenkel, Bar-Hillel, Levy en Van Dalen bestempel die verhouding tussen diskreetheid en kontinuitteit nie alleen as 'n sentrale gegewe nie, maar ook as die oudste probleem van die grondslae van die wiskunde en verwante gebiede. ${ }^{9}$ Hierdie outeurs meen tewens dat die ontdekking van inkommensurabiliteit die eerste krisis in die grondslae van die wiskunde ingelei het, met name in die Pythagoriese skool

8.'Jedes Zahlenverhältnis ließ sich ja geometrisch darstellien, aber nicht jedes Streckenverhältnis arithmetisch' (Lorenzen 1960:51).

9.In sy bekende geskrif Men of Mathematics meen E.T. Bell ook dat daar sedert die vroegste tye twee opponerende tendense in wiskunde was wat die hele ontwikkeling daarvan beheers het. 'Breedweg gesproke is dit die diskrete en die kontinue' (Bell 1965:12)
(Fraenkel et al. 1973:212). Om hierdie krisis te besweer is voorrang aan die geometrie bo die artimetika gegee, wat daartoe gelei het dat in Euklides se werke die teoretiese besinning oor getal as 'n onderdeel van die geometrie hanteer is (Lorenzen 1960:51).

Na die Middeleeue sou Descartes se analitiese meetkunde ' $n$ nuwe stimulus verleen aan die terugkeer tot ' $n$ aritmetisistiese benadering. Uiteindelik sou hierdie klemverskuiwing gedurende die 19de en vroeë 20ste eeue skynbaar weer die toonaangewende opvatting word. Een van die kernelemente in dié ontwikkeling is die problematiese gebruik wat van limiete gemaak is en wat tot die tweede grondslagkrisis van die wiskunde gelei het.

Die heersende siening was dat reële getalle as die limiete van konvergerende rye breuke gedefinieer kan word. Die probleem is egter dat enige getal wat as limiet figureer reeds 'n getal moes wees.

Hierdie probleem is skynbaar deur die daaropvolgende aritmetisering van Weierstrass in die tweede helfte van die 19de eeu te bowe gekom. Maar die optimisme wat dié aritmetiseringsproses vergesel het, sou spoedig in nuwe probleme vasloop, met name in die ongekwalifiseerde gebruik van die idee van 'n oneindige totaliteit (probleme wat in 1900, onafhanklik van mekaar, deur Russell en Zermelo ontdek is). Gray verbind die aard van 'n streng analise aan ' $n$ proses wat kulmineer in the crisis of continuity. ${ }^{10}$ Cantor se skynbaar onskuldige omskrywing van 'n versameling as bestaande uit wel onderskeie elemente wat tot 'n geheel saamgebind is (Cantor 18951897:481 en Cantor 1962:282), maak dit moontlik om 'n versameling te beskou wat ' $n$ element van sigself is as en slegs ás dit nie 'n element van sigself is nie (waar die elemente van $C$ al dié versamelings $A$ is wat sigself nie as 'n element bevat nie).

Hierdie verwikkelinge het die verband tussen kontinuïteit en oneindigheid op die voorgrond geplaas en tegelyk tot die bekende drie denkskole in die wiskunde van die 20ste eeu aanleiding gegee: die aksiomatiese formalisme, die logisisme en die intuïsionisme. Waar die aksiomatiese formalisme en logisisme beperkinge op Cantor se versamelingsleer wou plaas sodat Russell se versameling $C$ nie gekonsipieer kan word nie, het die intuïsionisme die idee verwerp van oneindige totaliteite (tradisioneel as die 'aktueel oneindige' aangedui) en ook die geldigheid van die logiese beginsel van die uitgeslote derde ten opsigte van die oneindige bevraagteken. Die aksiomatiese formalisme wou met behulp van aksiomas verhoed dat Russell se problematiese versameling C afgelei kan word, terwyl Russell gemeen het dat die oplossing daarin geleë is dat die wiskunde eintlik 'n onderdeel van die logika is. Die probleem was egter dat die oneindigheidsaksioma nie verlogiseer kon word nie (Fraenkel et al. 1973:186).

10.'This is the widespread feeling among mathematicians around 1900, documented in many sources, that the basic topic of analysis, continuity, was profoundly counterintuitive' (Gray 2008:20). 
Veral die reaksie van die intuïsionisme op hierdie derde grondslagkrisis van die wiskunde het teruggegryp na die Griekse filosofie en wiskunde. In 'n voordrag van Weyl in 1931 stel hy pertinent: 'Ja, juis nou word ons uitgenooi om oral in die grondslae van die wiskunde weer regstreeks na die Grieke terug te gryp' (Weyl 1931:1). Hy verwys spesifiek na 'n Fragment van Anaksagoras wat sê dat daar in dit wat klein is, geen kleinste is nie, maar slegs iets wat steeds kleiner is (Diels \& Kranz 1960-B:6). Met hierdie siening is die letterlike betekenis van 'sonder einde', van 'oneindig', na 'binne' gekeer. In plaas daarvan dat suksessie eindeloos voortgaan, word die opeenvolgende verdelings telkens op kleinerwordende dele afgestem. Met ander woorde, die intuïsionistiese opvatting van kontinuïteit (van die 'kontinuum' soos dit heet) sluit by die oneindige verdeelbaarheid daarvan aan soos dit reeds deur Anaksagoras en Aristotles na vore gebring is. Soos vroeër opgemerk is, meen Aristotles dat enigiets wat kontinu is, eindeloos verdeelbaar is in dele wat oneindig verder verdeelbaar is (Aristoteles, Phys. B 15-18); Aristoteles 2001:317).

Weyl omskryf die wiskunde graag as 'die wetenskap van die oneindige' (Weyl 1931:1):

As 'n mens ten slotte 'n kort trefwoord [wil aangee] wat die lewende middelpunt van die wiskunde raak, durf 'n mens wel sê: dit is die wetenskap van die oneindige. ${ }^{11}$

Die oneindige waarvan die intuïsionisme praat, is egter dit wat tradisioneel (op die voetspoor van Aristoteles) as die potensieel oneindige bekend gestaan het. Ons het vroeër daarop gewys dat Kant hierdie soort oneindigheid kernagtig saamvat in die uitdrukking: suksessief oneindig (sukzessivunendlich - Kant 1787-B:552).

Die suksessief oneindige vind 'n natuurlike toepassing op 'n eindelose suksessie sowel as op oneindige verdeelbaarheid. Daarom neem die intuïsionistiese waardering van die 'kontinuum' nie sy vertrekpunt in die verhouding van 'n element tot 'n versameling nie. Weyl meen gevolglik dat Brouwer se benadering van die deel tot die geheel eerder in ooreenstemming met die intuïsie van die 'wese' van die kontinuum is (Weyl 1966:74). Met inagneming van die ontwikkeling van die moderne topologie, verduidelik Weyl sy siening op 'n ooreenstemmende wyse in sy artikel oor die nuwe grondslagkrisis van die wiskunde. Hy argumenteer teen wat hy as die huidige 'atomisme' in die wiskunde tipeer. Sy eie benadering wil nie van punte uitgaan nie, maar van intervalle as primêre konstruksie-elemente van 'n kontinuum. Aangesien dit tot die wese van die kontinuum behoort dat 'elkeen van sy dele sig onbegrens verder laat verdeel', moet die begrip van ' $n$ 'punt' gesien word as die grensidee van 'n deling wat tot in die oneindige voortgesit is. Hy skryf:

Om die kontinue samehang tussen die punte weer te gee neem die kontemporêre analise, aangesien dit die kontinuum in ' $n$ versameling geïsoleerde punte uiteengebreek het, sy toevlug tot die omgewingsbegrip (Weyl 1921:77).

11.'Will man zum Schluß ein kurzes Schlagwort, welches den lebendigen Mittelpunk der Mathematik trifft, so darf man wohl sagen: sie its die Wissenschaft vom Unendlichen' (Weyl 1966:89. Sien ook Weyl 1932:7).
Wanneer Fraenkel et al. die intuïsionisme bespreek, verwys hulle onmiddellik na die gaping tusssen diskreetheid en kontinuiteit ('The abyss between discreteness and continuity' Fraenkel et al. 1973:210). Waar die klassieke 19de-eeuse analise (Weierstrass, Cantor, Dedekind: 1969) van die kontinuum as 'n aggregaat van bestaande punte uitgegaan het, het die intuïsionisme die suksessief oneindige aan die oneindige verdeelbaarheid van parsieel oorvleuelende dele verbind. Hierdie gedeeltelik oorvleuelende dele word by wyse van spreke as die manifestering van reële getalle gesien wat nog gegenereer gaan word:

The conception of the continuum as an aggregate of existing points (members), which is at the bottom of nineteenth century analysis and of Cantor's set theory, is replaced by an aggregate of parts which are partially overlapping and which is so to speak the manifestations of real numbers still to be generated (Fraenkel et al. 1973:256).

Opmerking: In sy 'conceptual structuralism' ontwikkel Feferman 'n beskouing waarin die rol van ons alledaagse ervaring erken en tegelyk op die aspekte van getal en ruimte geappelleer word. Nogtans beskou hy die 'basiese begrippe' van die wiskunde as gegewens wat slegs as 'mentale konsepsies' bestaan. ${ }^{12}$ Die term 'struktuur' verwys vir Feferman na groeperinge van samehangende objekte wat onderling verbind is deur ' $n$ paar eenvoudige relasies en bewerkings. Hy meen dat algemene idees soos 'orde, suksessie, versameling, relasie, reël en bewerking' die wiskunde voorafgaan en dat 'n 'implisiete verstaan daarvan noodsaaklik vir die verstaan van die wiskunde is' (Feferman 2008:3). Hy negeer egter die ontiese status van eienskappe wat op die aard van getals- en ruimteverhoudinge appelleer. Orde en suksessie is immers oorspronklike aritmetiese gegewens. Die getalsmatige orde van opeenvolging maak die feitlike suksessie van enige 'getalle-ry' eers moontlik. Insgelyks omskryf Feferman die aard van 'n 'struktuur' in ruimtelike terme - soos 'samehangend' (ekwivalent aan gekonnekteerd of kontinu) en 'onderlinge verbondenheid' (eweseer sinoniem aan gekonnekteerd of kontinuïteit) - sonder om in te gaan op die uniekheid en samehang tussen die onties gegewe aspekte van getal en ruimte.

Die verhouding tussen diskreetheid en kontinuïteit verskyn steeds in besinnings oor die grondslae van die wiskunde. Fraenkel et al. stel kategories dat die probleem om die 'gaping tussen die domeine van diskreetheid en kontinuïteit, of tussen die getalleleer en die meetkunde te oorbrug, 'n sentrale, ongetwyfeld selfs dié sentrale probleem van die fundering van die wiskunde' is (Fraenkel et al. 1973:211).

Fraenkel et al. meen dat om die aard van hierdie probleem te deurgrond, die fundamentele verskil is tussen:

... the discrete, qualitative, individual nature of number in the 'combinatorial' domain of counting (arithmetic) and the continuous, quantitative, homogeneous nature of the points of space (or of time) in

12. Hierdie siening kontinueer die moderne nominalisme warvolgens geen universaliteit buite die menslike gees bestaan nie. Descartes stel reeds dat 'getal en alles wat universeel is slegs modi van denke is' (Descartes 1965b:187; Deel I, § LVIII). 
the 'analytical' domain of measuring (geometry). (Fraenkel et al. 1973:212). ${ }^{13}$

Hoewel Frege die wiskunde bloot op die basis van 'suiwer logiese beginsels' wou opbou, moes hy toegee dat die vroeër vermelde ontdekking van Russell insake die versameling $C$ (wat bestaan uit alle versamelings $A$ wat sigself nie as element bevat nie) sy program gekelder het. Gevolglik sou hy teen die einde van sy lewe die sirkel voltooi deur opnuut terug te keer na 'n ruimteperspektief:

The more I have thought the matter over, the more convinced I have become that arithmetic and geometry have developed on the same basisa geometrical one in fact - so that mathematics in its entirety is really geometry (Frege 1979:277).

Sedert die begin van hierdie eeu het daar opnuut wiskundiges na vore getree wat prioriteit verleen aan die 'kontinuum'. Volgens Longo gaan kontinuïteit in 'n ontologiese sin aan diskreetheid vooraf ${ }^{14}$, want na sy mening is laasgenoemde bloot 'n 'ongeluk', 'n 'gebroke lyn' (Longo 2001:6). Longo kombineer ook die opvattings van Leibniz en Thom insake die oorspronklike gegewendheid van die kontinuum, wat volgens hulle 'sentraal staan in alle wiskundige konstruksies - en kontrasteer dit dan met die diskrete wat slegs verteenwoordig word as 'n singulariteit, as 'n katastrofe' (Longo 2001:19).

In onderskeiding van die dominante versamelingsteoretiese aritmetisisme van die 19de en 20ste eeue het daar teen die laat sestigerjare en vroeë sewentigerjare van die vorige eeu die sintetiese differensiaalgeometrie ontstaan wat ook bekend staan as Smooth Infinitesimal Analysis (SIA). Kontinuiteit ontvang 'n besondere plek in hierdie ontwikkelinge. Die wyse waarop John Bell kontinuïteit omskryf, besit raakpunte met wat ons reeds oor die aard van kontinuïteit uitgelig het. Hy skryf:

To be continuous is to constitute an unbroken or uninterrupted whole, like the ocean or the sky. A continuous entity - a continuum - has no 'gaps'. Opposed to continuity is discreteness: to be discrete is to be separated, like the scattered pebbles on a beach or the leaves on a tree. Continuity connotes unity, discreteness plurality (Bell 2006:13-14).

Wat vir ons tema van besondere belang is, is die erkenning van beide diskreetheid en kontinuïteit in hul eie reg. Bell stel immers dat SIA prioriteit verleen aan die kontinue as "n outonome nosie' wat 'nie in terme van die diskrete verduidelik kan word nie' (Bell 2006:284). Hieraan voeg hy op die volgende bladsy toe dat in SIA álle funksies of korrelasies tussen wiskundige objekte 'smooth' is en derhalwe in die besonder kontinu is: 'Accordingly SIA realizes in a very strong way Leibniz's principle of continuity: natura non facit saltus'.

Die verskil tussen (heel-)getalle en die 'kontinuum' word soos volg deur Fraenkel et al. verduidelik:

13. Hierdie werk van Fraenkel et al. bly nog steeds gesaghebbend ten opsigte van die aksiomatiese fundering van die versamelingsleer. Maddy beroep haar gereeld daarop (sien Maddy 1997:14, 39-42, 47-48, 50, 52-54, 57-58, 61, 85).

14.Die titel van ' $n$ Franse geskrif wat Thom in 1992 die lig laat sien het, beklemtoon ook dat die ontologiese die kontinue voorafgaan bo die diskrete: 'L'Antériorite Ontologique du Continu sur le Discret' (Thom 1992).
Every integer differs from every other in characteristic individual properties comparable to the differences between human beings, while the continuum appears as an amorphous pulp of points which display little individuality (Fraenkel et al. 1973:212).

Laugwitz sluit hierby aan wanneer hy skryf: "n Punt in die geometriese kontinuum is - volgens Euklides - iets wat geen dele het nie, derhalwe letterlik genome ook 'n individu, maar een sonder kenmerkende eienskappe; dit is nie moontlik om een punt van 'n ander een te onderskei nie. 'Geen reguit lyn of vlak is van 'n ander reguit lyn of vlak onderskeibaar nie' (Laugwitz 1986:9).

Hieruit trek Laugwitz 'n gevolgtrekking wat aritmetisistiese wiskundiges nie in hul spreke oor die 'continuum' verreken nie. Hy wys daarop dat die 'versamelingsbegrip van meet af so ontwerp is, dat dit wat kontinu is sig aan die greep daarvan onttrek'. Die versamelingsbegrip handel volgens Cantor immers oor 'n 'samevatting van welonderskeie objekte', wat aandui dat die 'diskrete heers' (Laugwitz 1986:10). Gevolglik merk hy ook op dat die gebruik van die woord 'kontinuum' in die kontemporêre wiskunde deur die versamelingsteorie beïnvloed is.

Ondanks die afwisseling van pogings om kontinuïteit eksklusief aritmeties of geometries te verstaan, bevestig die geskiedenis van die filosofie en die wiskunde dus onteenseglik dat beide verklaringswyses 'n konstante metgesel van besinning oor die aard van kontinuïteit en diskontinuïteit was. Dat dit ook die geval in die fisika en biologie was, sal in 'n aparte artikel aangetoon word.

Figuur 1 wat handel oor die uniekheid en samehang tussen getal en ruimte kan in 'n sekere sin dien as 'n kernagtige opsomming van die sistematiese gesigspunte wat uit die

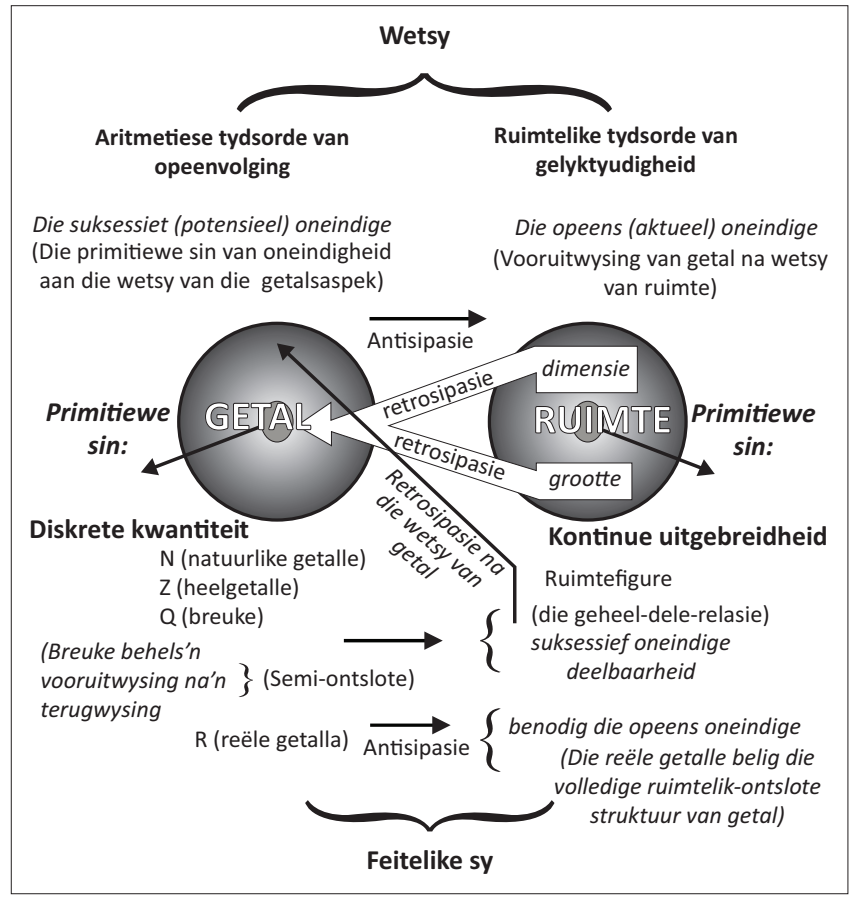

FIGUUR 1: Die wederkerige samehang en onherleibaarheid van getal en ruimte. 
geskiedenis na vore getree het. Die onderskeiding tussen wetsy en feitelike sy word beliggaam in die tydsordes van opeenvolging en gelyktydigheid en hierdie tydsordes korreleer met verskillende getaltipes (natuurlike getalle, heelgetalle, breuke en reële getalle) en met die feitlike ruimtelike geheel-dele-relasie. As al die dele van 'n ruimtefiguur nie gelyktydig (opeens) aanwesig is nie, bestaan dit nie in sy geheel nie. Die erkenning van hierdie twee tydsordes vorm die basis van wat tradisioneel as die potensieel en die aktueel oneindige beskou is, maar wat intuïtief duideliker aangedui sou kon word as die suksessief oneindige (dink aan die uitspraak van Kant was hierbo aangehaal is) en die opeens oneindige. Die sonderlinge verhaal wat die geskiedenis oor die aard van kontinuïteit en diskontinuiteit in die wiskunde vertel, is dat steeds heen en weer beweeg is tussen die strewe om alles vanuit 'n getalsperspektief of vanuit 'n ruimteperspekief te verklaar sonder dat die alternatief wat in die diagram vervat is, oorweeg is: aanvaar die uniekheid en onherleibaarheid van diskreetheid en kontinuïteit (getal en ruimte) en ondersoek dan op daardie basis hul wederkerige samehang.

\section{Erkenning \\ Mededingende belange}

Die outeur verklaar dat hy geen finansiële of persoonlike verbintenis met enige party wat hom nadelig of voordelig kon beïnvloed het in die skryf van hierdie artikel nie.

\section{Literatuurverwysings}

Aquinas, Th., 1945, Basic writings of saint Thomas Aquinas, with an introduction by Anton C. Pegis, Random House, New York.

Aristotle, 2001, The basic works of Aristotle, Richard McKeon (ed.) with an introduction by C.D.C. Reeve, (originally Random House [1941]), The Modern Library,
New York.

Bell, E.T., 1965, Men of Mathematics, Volume 1, Penguin Books, Harmondsworth.

Bell, J.L. 2006, The continuous and the infinitesimal in Mathematics and Philosophy, Corso Polimetrica, Monza Milano.

Breidert, W., 1976, 'Kontinuitätsgesetz', in Historisches Wörterbuch der Philosophie, J. Ritter, K. Gründer \& G. Gabriel (Red.), Band 4 (pp.1042-1044), Schwabe \& Co, Basel-Stuttgart.

Cantor, G., 1895, 'Beiträge zur Begründung der transfiniten Mengenlehre', in Mathematische Annalen, Band 46 (pp.481-512) und 1897 Band 49 (pp.207-246)

Cantor, G., 1962, Gesammelte Abhandlungen Mathematischen und Philosophischen Inhalts, Oldenburg Verlag (1932), Hildesheim.

Cantor, G., [1895-1897] 1962, 'Beiträge zur Begründung der transfiniten Mengenlehre', Mathematische Annalen, 46:481-512 [1895]; Beiträge zur Begründung der transfiniten Mengenlehre, Mathematische Annalen, 49:207-246 [1897].

Dedekind, R., [1872] 1969, Stetigkeit und Irrationale Zahlen, Siebente Auflage, Friedrich Vieweg \& Sohn, Braunschweig.
Descartes, R., 1965a, A discourse on method, meditations and principles, trans. John Veitch, with an introduction by A.D. Lindsay, Everyman's Library, London.

Descartes, R., 1965b, The Principles of Philosophy, in A discourse on method, meditations and principles 1965:147-228.

Diels, H., Kranz, W., 1959-1960, Die Fragmente der Vorsokratiker, Bänden I-III., Weidmannsche Verlagsbuchhandlung, Berlin.

Feferman, S., 2008, 'Conceptions of the continuum', viewed on 15 March 2016 pp. 1-28 from: https://math.stanford.edu/ feferman/papers/Continuum-l.pdf

Fraenkel, A., Bar-Hillel, Y., Levy, A., Van Dalen, D., 1973, Foundations of set theory, 2nd ed., North Holland, Amsterdam.

Fränkel, H., 1968, 'Zeno von Elea im Kampf gegen die Idee der Vielheit', in Um die Begriffswelt der Vorsokratiker, Wege der Forschung, Band IX, H-G. Gadamer (ed.), Wissenschaftliche Buchgesellschaft, Darmstadt.

Fischer, L., 1933, Die Grundlagen der Philosophie und der Mathematik, Felix Meiner Verlag, Leipzig.

Frege, G., [1884] 1934, Grundlagen der Arithmetik, Ursprünglich 1884 in Breislau, Verlag Wilhelm Koebner, Unveränderter Nachdruck 1934, Verlag M \& H. Breslau, und in letzter Zeit Frege, G., 2001, Grundlagen der Arithmetik, Reclam, Stuttgart.

Frege, G., 1979, Posthumous writings, Basil Blackwell, Oxford.

Gray, J., 2008, Plato's ghost: The modernist transformation of mathematics, Princeton University Press, Princeton.

Hasse, H. \& Scholz, H., 1928, 'Die Grundlagenkrisis der griechischen Mathematik', in Kant-Studien, Vol. 33:4-35.

Kant, I., 1787, Kritik der reinen Vernunft [1956], Felix Meiner Verlag, Hamburg.

Laugwitz, D., 1986, Zahlen und Kontinuum. Eine Einführung in die Infinitesimalmathematik, B.I.-Wissenschaftsverlag, Mannheim.

Leibniz, G.W.H., 1965, 'New essays on the human understanding' (1765), published in M. Morris (ed.), Leibniz: Philosophical writings, Everyman's Library, London.

Leibniz, G.W.L., 1976, Philosophical papers, Leroy E. Loemker (ed.), Volume 2, Synthese Historical Library, (first imprint 1969), D. Reidel, Dordrecht, Holland

Longo, G., 2001, 'The mathematical continuum: From intuition to logic', viewed on 14 May 2011 from: http://ftp.di.ens.fr/pub/users/longo/PhilosophyAndCognition/ the-continuum.pdf

Lorenzen, P., 1960, Die Entstehung der exakten Wissenschaften, Springer-Verlag, Berlin. https://dx.doi.org/10.1007/978-3-642-86242-7

Maddy, P., 1997, Naturalism in mathematics, Clarendon Press, Oxford.

Maddy, P., 2005, 'Three forms of naturalism', in S. Shapiro (ed.), The Oxford Handbook of Philosophy of Mathematics and Logic, pp. 437-460, Oxford University Press, New York. https://dx.doi.org/10.1093/0195148770.003.0013

Murdoch, J.E., 1969, 'The rise and development of the application of mathematics in fourteenth century Philosophy and Theology', in Arts libéraux et philosophie au moyen âge, Montréal/Paris, pp. 238-246.

Murdoch, J., 1982, 'Infinity and continuity,' in N. Kretzmann, A. Kenny \& J. Pinborg (eds.), The Cambridge history of later medieval philosophy, pp. 564-591 Cambridge University Press, Cambridge. https://dx.doi.org/10.1017/ CHOL9780521226059.031

Sinnott, E.W., 1963, The problem of organic form, Yale University Press, London.

Sylla, E.D., 1973, 'Medieval concepts of the latitude of forms: The Oxford Calculators', Archives d'histoire doctrinale et littéraire du moyen âge, 40: 223-283.

Thom, R., 1992, L'Antériorité Ontologique du Continu sur le Discret, in J.-M. Salanskis \& $\mathrm{H}$. Sinaceur, Le Labyrinthe du Continu, Springer-Verlag, Berlin.

Weyl, H., n.d. 'Über die neue Grundlagenkrie der Mathematik, Mathematische Zeitschrift', Band 10:39- 79.

Weyl, H., 1931, 'Die Stufen des Unendlichen', Vortrag am 27ten Oktober 1930 bei der Eröffnung der Gästetagung der Mathematischen Gesellschaft an der Universität von Jena in Abbeanum, pp. 1-19.

Weyl, H., 1932, The open world, Yale University Press, New Haven.

Weyl, H., 1966, Philosophie der Mathematik und Naturwissenschaft, 3de wesentlich erweiterte Auflage, Wissenschaftliche Buchgesellschaft, Wenen.

Yourgrau, P., 2005, A world without time: The forgotten legacy of Gödel and Einstein, Penguin Books, London. 